\section{Off-centered Butuan: A critical analysis of instructional materials and classroom interactions in the mother tongue-based multilingual education in Butuan City}

\section{Tagyamon, Castor Jr.}

Humanities, Social Sciences, and Communication Department, Far Eastern University - Institute of Technology, Philippines (castortagyamonjr@gmail.com)

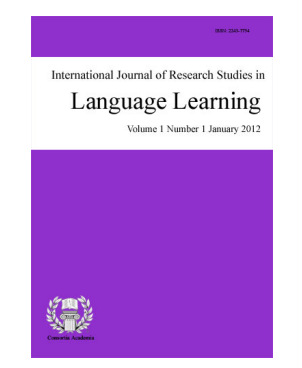

ISSN: 2243-7754 Online ISSN: 2243-7762

OPEN ACCESS

\title{
Abstract
}

Since June 2012 the Department of Education (DepEd) in Butuan City has implemented the Mother Tongue-Based Multilingual Education (MTB-MLE). The program promotes the teaching of Cebuano, Filipino, and English as language subjects particularly to grade one public elementary students in Butuan. The department believes that the teaching of Cebuano, students' mother tongue in Butuan, will bring students close to their Butuan culture; Filipino will help them to communicate with other Filipinos who belong to various cultural groups; and English will connect them to the cultures of the world. To know whether there is a one-to-one correspondence between language subjects and cultures taught to students is the main objective of this study. More specifically, this study compares, contrasts, and evaluates the cultural discourses or schematic representations of cultures present in instructional materials (IMs) (i.e. word cards, images, and stories or big books) and classroom interactions in the three language subjects of five grade one sections of one school in Butuan. A word card normally contains one word with no clear cultural contents. Images produce mixed cultural messages. Stories or big books generally portray the Filipino culture. In general, classroom interactions using IMs center on students' Butuan culture. The interactions suggest that the learning of second languages (i.e. Filipino and English) does not necessitate the learning of cultures unfamiliar to students. Thus far, incongruities exist between the MTB-MLE program on paper and the same program in action. More work, therefore, needs to be done to improve the program.

Keywords: MTB-MLE; language subjects; instructional materials; classroom interactions; cultural discourse 


\section{Off-centered Butuan: A critical analysis of instructional materials and classroom interactions in the mother tongue-based multilingual education in Butuan City}

\section{Introduction}

\subsection{The Mother Tongue-Based Multilingual Education in Butuan City}

In compliance with Department of Education (DepEd) Order No. 74, series of 2009, the Department of Education (DepEd) in Butuan City implemented in June 2012 the Mother Tongue-Based Multilingual Education (MTB-MLE) in the city (D. Tampus, personal communication, January 7, 2012; for more information on DepEd Order No. 74, series of 2009, see Nolasco, Datar, \& Azurin, 2010). The order promotes "the effective use of more than two languages for literacy and instruction (as cited in Cruz, 2010, p. 60). Aside from learning Filipino, the country's official and national language, and English, a language used for international communication (Ammon, 2010; Official Gazette, 2015), students under MTB-MLE are given opportunities to learn their native or mother tongue formally in school. Native or mother tongue is defined as the language spoken by at least one of students' parents or by many members in students' communities (Calvet as cited in Phillipson, 1992, p. 39). Because students normally hear this language in day-to-day interactions, they become motivated to acquire the language first, know it best, or use it most (United Nations Educational, Scientific and Cultural Organizations [UNESCO] as cited in Nolasco, 2009, p. 2).

Depending on locality, a mother tongue subject taught under the MTB-MLE can be Tagalog (with an estimate of 21.5 million native speakers), Cebuano (18.5 million), Ilokano (7.7 million), Hiligaynon (6.9 million), Bikol (4.5 million), Waray (3.1 million), Kapampangan (2.3 million), Pangasinense (1.5 million), Maranao (1 million), and Maguindanaoan (1 million) (2000 Philippine census as cited in Nolasco, 2008; Nolasco et al., 2010, p. 134). In Butuan City, Cebuano and Butuanon are two vernacular languages ("City Government of Butuan," 2012). Butuanon is the city's native language, yet very few Butuanon people can speak it (Manila Times, August 11, 2007 as cited in David, Cavallaro, \& Coluzzi, 2009, p. 176). Having 18.5 million native speakers, Cebuano has become a regional lingua franca in the Visayas and Mindanao regions (Nolasco, 2008). The predominance of Cebuano over Butuanon impels DepEd Butuan to select the former as the mother tongue subject in almost all public elementary schools under the MTB-MLE in Butuan City (D. Tampus, personal communication, January 7 , 2012).

Cebuano is taught from grades one to three, whereas Filipino and English are taught all throughout elementary and high school (see Nolasco, 2010; Sy-Kho, 2012). Teaching Cebuano and Filipino in the first grade starts in June or the first month of a school year (S.Y.), while teaching English commences in the first week of November or in the third quarter (R. Collado, personal communication, September 23, 2013). In 2012, the MTB-MLE program covered only kindergarten and the first grade (for more information, see Nolasco, 2010; Sy-Kho, 2012). It extended to grade two in 2013. This means that in every year thereafter another grade level is added until such time that all levels in elementary and high school are covered by the program (Nolasco, 2010).

The implementation of the MTB-MLE in the Philippines is in line with linguistic and cultural diversity in education espoused by the United Nations Educational, Scientific and Cultural Organization (UNESCO). UNESCO (2003) believes that education should not only train students to engage in national and global participation but also address the idiosyncratic linguistic and cultural needs of their individual communities. By teaching them their mother tongue, students will develop deep appreciation and knowledge of their own language and culture (UNESCO, 2003; see also Ball, 2010). The interrelationship between language and culture has been one of the key matters of interest in the annals of language education. 
A critical analysis of instructional materials and classroom interactions in the mother tongue-based education

\subsection{Cultural discourses in English language education}

Studies in English language education are replete with mainly analysis of English textbooks. Broadly conceived of as texts (Bloor \& Bloor, 2007), textbooks and other instructional materials consist of semiotic modes which are defined by van Leeuwen (2005) as a meaningful resource of information.

Modes can be grouped into four categories. Linguistic modes are words found in written texts; oral modes are utterances in oral communication; photos, maps, and images of cartoons are examples of visual modes; and materiality refers to the surfaces of production (e.g. paper, rock, plastic, etc.), substances of production (e.g. ink, gold, and paint), and tools of production (e.g. pencil and brush) (Kress \& van Leeuwen, 2006). The interplay of these semiotic modes produces a cultural discourse or a socially constructed schematic knowledge and representation (Fairclough, 1995a, 1995b; van Leeuwen, 2005) of people, products, places, practices, and perspectives of a culture (Moran, 2001).

Various, and sometimes contradictory, cultural discourses attempt to explain the interrelationship between language and culture in English language education. English cultural imperialism is a discourse that is biased towards the culture of native speakers of English (Phillipson, 1992). It labels native English speakers in North America, Britain, Australia, and New Zealand as either "the center" (Canagarajah, 1994; Jahan, 2012) or "the target culture" (Göldner, 2011; Jahan, 2012; Mahmood, Asghar, \& Hussain, 2012). Textbooks portray native English teachers as the best examples or models of the language (for more, see Phillipson, 1992), and representations of places (e.g. London and Geneva College in America), among other things, are mainly those found in "the center" or "the target culture" (Canagarajah, 1999; Shah, Afsar, Fazal e Haq, \& Khan, 2012).

Unlike English cultural imperialism, English internationalism and cosmopolitanism views all English language varieties as equal, and it gives native speakers of English no exclusive rights to own the language (Crystal as cited in Ciprianová \& Vanco, 2010, p. 127; see also Jambor, 2007). One World for Secondary English, a book written by Priesack and Tomscha in 1993, comes with an audio file, showcasing various English accents of speakers around the world (Cortazzi \& Jin, 1999). Cutting Edge: Intermediate photographs Mahatma Ghandi, Bill Gates, David Beckham, Serena Williams, Nelson Mandela, J.K. Rowling, and Pablo Picasso as world famous personalities (Block, 2010).

The third type of cultural discourse limits representations to two cultural groups-the culture of native speakers of English and students' native culture. Such representations, which are labeled under bicultural discourse, are evident in some of the ministry-approved English language textbooks in Japan (Göldner, 2011). In Sunshine, Total English, One World, and Columbus 21, the characters are named using the writing and sound systems of their native languages (see Göldner, 2011). Some names of Japanese characters are Koji, Yuki, Hiro, Emi, Aki, Kenta, and Shin, while those who are not Japanese are Mike from Australia, Lisa and Mike from Canada, and Andy, Jenny, and Judy from America (Göldner, 2011; see also Tajima, 2008). The books showcase exchanges of cultural practices and perspectives between Japanese and native speakers of English. For instance, Hiro's family experiences how Jenny and other Americans spend Halloween and Christmas (Tajima, 2008).

Whereas the first three cultural discourses include, to a varying extent, knowledge and representations about native speakers of English, the source cultural discourse uses only students' source culture. "Source culture" is broadly defined as the culture of non-native English speaking students (Göldner, 2011; Jahan, 2012; Mahmood et al., 2012). Students in Turkey use Spotlight on English, a book written by Dede and Emre in 1988, whose content is anything that Turkish students can easily relate to (see Cortazzi \& Jin, 1999). Topics such as Turkish food, history, and weather are some of the local contents in the book (Cortazzi \& Jin, 1999). As its book title suggests, English for Saudi Arabia (1988) informs Saudi Arabian students about their people (e.g. Arabian profession), products (e.g. Arabian coffee), and practices (e.g. pilgrimage to Mecca) (Cortazzi \& Jin, 1999).

Thus far, the literature on English language education has shown that the contents of textbooks are not devoid of cultural meanings. Much like other texts, textbooks are, according to Fairclough (1995a, 1995b), part 
of bigger contexts. They may reflect commonsensical or dominant views of society like the idea that English can be best learned under the teachings of a native speaker of the language (for related arguments, see Phillipson, 1992), or they may challenge and transform such views (see Fairclough, 1995a, 1995b).

Despite the richness of the analysis of textbooks in English language education, there are areas that are not yet fully explored. Scholars rarely investigate critically the actual consumption of instructional materials (IMs) in class. Canagarajah's (1999) attempt to understand students' writings, glosses, and drawings in their English textbooks reveals students' struggles and feelings of ambiguities against the English language. Canagarajah (1999), however, fails to discuss in detail classroom or teacher-student oral interactions using IMs. Such interactions may produce cultural discourses that can be either consistent with or opposite to the cultural discourses already present in the IMs.

Aside from the lack of studies on classroom interactions, analysis of instructional materials (IMs) besides textbooks is rarely done. Not all textbooks are used in class, and not all classes use textbooks. Some textbooks are not even culturally relevant to students (see Canagarajah, 1999; Shah et al., 2012). The use of culturally relevant instructional materials is one of the goals of the Mother Tongue-Based Multilingual Education (MTB-MLE) in the Philippines. Support from and involvement with community members such as elders, educators, parents, and local "experts" are considered in producing locally relevant materials (Ball, 2010; see also Nolasco et al., 2010). The knowledge, skills, stories, songs, and culture of students can be considered as educational resources (Malone, 2007). How true this is in the actual implementation of the MTB-MLE in Butuan City is one of the areas that this present study finds worth investigating.

Because there is not much information known yet about the actual implementation of the MTB-MLE in Butuan City, this study had to select only one school to serve hopefully as a precursor to conducting studies of wider scope in the future. Classrooms of grade one teachers were selected as sources of data. Compared to teachers in grade two, grade one teachers had more years of experience teaching under the MTB-MLE, which helped them adjust to the requirements of the program.

\subsection{The research questions}

The research questions of this study are based mainly on the goals of MTB-MLE and the perceived cultural and instrumental significance of language subjects. According to Nolasco (2009), MTB-MLE produces multi-literate, multilingual, and multicultural learners. In the same vein, Philippine President Benigno "PNoy" Aquino III claims that mother tongue, Filipino, and English have distinct cultural significance. He argues that learning mother tongue-Cebuano in the case of Butuan - will connect students to their city's local heritage, Filipino to the Philippine country, and English to the world (Aquino as cited in Nolasco, 2010, p. 107).

In connection to the statements above, should there be a one-to-one correspondence between language subjects and cultures? More specifically, are Cebuano, Filipino, and English subjects in grade one taught to learn the Butuan, Filipino, and world/international cultures, respectively? Are cultural discourses in instructional materials the same as those constructed in classroom interactions? What are the causes of the correspondences or similarities and dissimilarities of cultural discourses within and among language subjects? What are the implications of such correspondences and incongruities? What should the Department of Education do to address if there are any issues in the implementation of the MTB-MLE?

\subsection{Significance of the study}

Among the three language subjects, it is English that is undoubtedly the most popular because it is learned as an additional language to students all over the world (see Phillipson, 1992). English is dominant, so much so that a lot of scholarship focuses on the language. In this study on the MTB-MLE, the inclusion of the Cebuano and Filipino subjects can demonstrate that the kinds of analysis done for the English language can also be done for other languages. Like English, Cebuano and Filipino are legitimate languages worthy of investigation. 
A critical analysis of instructional materials and classroom interactions in the mother tongue-based education

In this study, IMs are not limited to textbooks. Whereas the existing literature is unfortunately preoccupied with textbook analysis, this study does more by showing that other instructional materials such as images and stories which are used in language classrooms are as equally important as textbooks. Extending the analysis to various instructional materials can challenge scholarship which has been so comfortable with easy access of materials to analyze. Not all textbooks are used in class and not all classes use textbooks.

A lot of studies begin and end their analysis only with IMs. No matter how many IMs are analyzed, the findings cannot determine and explain fully the interactive exchanges between teachers and students inside their classrooms. The use of classroom interactions as another source of data adds up to the overall significance of this study. Understanding interactions inside classrooms can be more insightful than an independent study of IMs without actual context of use.

The findings from the analyses of instructional materials and classroom interactions together may encourage rethinking of notions of multilingualism and multiculturalism in language education. As mentioned by President Aquino III, there appears a one-to-one correspondence between language subjects and cultures. This simplistic notion of multilingualism and multiculturalism in language education can be a problem because it may not welcome the use of one language to explore various cultures and the expression of one culture using different languages.

Most importantly, the findings of this study can help administrators and officials in their language education planning, policy, and implementation. By observing classrooms, this study can uncover the real conditions of teachers and students under the MTB-MLE to evaluate whether the program is consistent on paper and in action (for more about ethnography in education, see Wolcott, 1987). The evaluation of the MTB-MLE, however, does not have to revolve only around the shortcomings of the program, if there are any. In the end, this study can be used by the Department of Education to come up with plans to develop, whenever necessary, the MTB-MLE program. Similarly, educational institutions and government organizations within and even outside the Philippines can use this study as their reference to their reconsideration of their own language education policies.

\section{Materials and Methods}

\subsection{Data collection procedure}

This study combined the two broad traditions of research: quantitative (i.e. descriptive statistics) and qualitative (i.e. case study, exploratory, ethnography, and textual analysis) approaches. Information about the MTB-MLE in Butuan City is scarce, so this study had to begin exploring the vast and barely known field by selecting one school as a case to describe, interpret, and evaluate the new program in the city. Exploring meant going into the actual classroom contexts and observing what was ordinary for a considerably long period of time.

Classroom observations, Critical Discourse Analysis (CDA) paired with Kress and van Leeuwen's Multimodality, and a focus group discussion (FGD) were the three specific research methods of this study. The classroom observations were necessary to collect actual instructional materials and to observe their actual context of use. Classroom interactions from August 20, 2013 to December 6, 2013 were video recorded. Fairclough's Critical Discourse Analysis (CDA), paired with Kress and van Leeuwen's Multimodality, was conducted to examine two major types of texts - the instructional materials and the classroom interactions (more about this in the data analysis procedure). A focus group discussion (FGD) with the teachers and the school principal was supplementary to the first two methods. The FGD was conducted a few days after the end of the classroom observations to either challenge or validate the study's initial observations.

\subsection{Research locale and participants}

The principal of a school—which must not be named—selected five grade one teachers who handled 
Tagyamon, C., Jr.

different sections or classifications of students. Each teacher taught the Cebuano, Filipino, and English subjects. Purposively selecting the best teachers in the school as the principal's reason was ruled out because, based on the actual classroom observations, not all of the five teachers were confident about their teaching. It was observed that one of the teachers lacked classroom management skills. Her students were noisy talking, playing, and running within their classroom despite the teacher's constant reminder to behave. The five grade one teachers were given pseudonyms (Teachers A, B, C, D, and E). Their students' identities, too, remained hidden.

\subsection{Data analysis procedure}

The total number of classroom observations per subject per teacher was counted. Only three common types of instructional materials (IMs) were described, examined, interpreted, and evaluated for a few reasons. These three common IMs were tangible, could be kept, and could be used and reused in oral interactions between teachers and students. Other IMs were used infrequently, so they were assessed to be of least importance to the teachers and to this study as well.

Descriptive statistics and in-depth discussions complemented each other in the analysis of IMs and classroom interactions. The statistics dealt with numbers to highlight salient cultures and cultural elements. The in-depth discussions were guided by Fairclough's Critical Discourse Analysis (CDA) and Kress and van Leeuwen's Multimodality. Fairclough's CDA has three levels of analysis: description, interpretation, and explanation (1989). Description is the textual analysis of formal properties of texts (Fairclough, 1989; see also Tupas, 2002). In this level, the interplay of four semiotic modes—linguistic, oral, visual, and materiality-in constructing cultural discourses is discussed.

During the interpretation stage, texts are viewed as part and parcel of institutional contexts (Fairclough, 1989, 1995a, 1995b). Texts are not independent entities but products of production and resources for consumption (Fairclough, 1989). Here, findings from the textual analysis are linked to institutional practices or to the practice of making texts (see Fairclough, 1989; Tupas, 2002) and to the perceived interests of producers and consumers of texts (Fairclough, 1989).

The final level is the analysis of social practices, where the word 'social' encapsulates all the processes-political, economic, global, etc.— in which human beings take part (Fairclough, 1995b; Titscher, Meyer, Wodak, \& Vetter, 2000). This stage is a critique of the dialectical and complex relationship between texts and society (Fairclough, 1995a, 1995b). Texts can perform two functions. They may either reflect dominant and commonsensical views of society or challenge and transform such views (Bloor \& Bloor, 2007; Fairclough, 1989).

\section{Results}

\subsection{Types and general characteristics of instructional materials}

76 classroom meetings or sessions were observed, 30 of which were in Cebuano, 29 in Filipino, and 17 in English. The subject with the least number of observations was English since it started only in November, the third quarter of the school year.

The classroom observations recorded diverse kinds of instructional materials (IMs). There were writings on the board, written exercises, poems written on manila paper, real and other three dimensional objects (e.g. bag, notebook, pencil, ball, and toy fruits), an English booklet on antonyms containing images of animals such as bears, hippopotamus, owls, etc. which was used in a Cebuano class, and activity booklets in Cebuano and in English that were provided by the Department of Education. The activities in the booklets included, but were not limited to, drawing, coloring, matching type, providing correct answers, etc. The three most commonly used IMs were word cards, images, and stories or big books. 
A critical analysis of instructional materials and classroom interactions in the mother tongue-based education

Table 1

Total classroom observations

\begin{tabular}{lcccc}
\hline \multicolumn{1}{c}{ Teacher } & Cebuano & Filipino & English & Total \\
\hline Teacher A & 7 & 7 & 4 & 18 \\
Teacher B & 7 & 7 & 5 & 19 \\
Teacher C & 7 & 7 & 4 & 18 \\
Teacher D & 5 & 4 & 1 & 10 \\
Teacher E & 4 & 4 & 3 & 11 \\
\hline Total & 30 & 29 & 17 & 76 \\
\hline
\end{tabular}

\subsection{Cultural discourses in word cards}

Word cards, which are called by teachers as name cards, contain not just common and proper names of people, places, and things. Some words were adjectives and verbs, each of which was written on a piece of bond paper, if not on a piece of 'cartolina' (a poster paper). Words were written by the teachers either manually or with the help of computer technology. A normal size of a word card was equivalent to a one-fourth size of bond paper.

There were 146 word cards in Cebuano, 108 in Filipino, and 65 in English. In Cebuano, almost half of the word cards (47\%) were nouns, $27 \%$ were adjectives, $15 \%$ were verbs, and $11 \%$ contained words referring to titles of lessons (e.g. common nouns, proper nouns, suhing-pulong [antonyms], and kapulong [synonyms]).

Thirty-two percent of the word cards in Filipino pertained to titles of lessons. Twenty-seven percent were one-word verbs or action words; $16 \%$ were adjectives which were too varied and difficult to categorize (e.g. maaga [early] and malaki [big]). The rest were common names of places, buildings, and establishments.

Thirty-five percent of the word cards in English referred to body parts. Another 35\% were common names of animals. Eleven percent were titles of English lessons; nine percent referred to noun phrases or things with colors as modifiers (e.g. a pink rose, a red ribbon, a green watermelon); six percent to phrases or clauses which did not necessarily make sense when put together (i.e. you will like, a little rabbit, has run away, for the girl); The remaining percentage was difficult to categorize.

Generally, word cards were not contextualized. The ideas they conveyed were not necessarily culturally specific. Proper nouns provided hints to a culture (i.e. Gido, Elena, Bb. Rosa [Ms. Rosa], Adidas [a shoe brand], Nido [a brand of milk], and Mongol [a brand of pencil]), but only to a point of identifying a person or thing. Descriptions, connotations, or cultural meanings attached to them were not available. On the other hand, word cards containing adjectives provided descriptions but the people, products, places, and practices they modified were missing. Lastly, verbs were potentially about practices, but information about the person who did any of the actions to whom and in what conditions was not given.

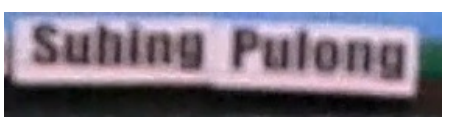

[Antonyms]

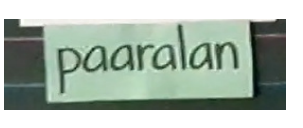

[School]

Figure 1. Word cards in Cebuano, Filipino, and English

\subsection{Cultural discourses in images}

Images contained mainly visual modes about people, products, places, and practices. Some images were printed, while others were manually drawn. Some were colored, some were not. Normally the paper used to draw or print an image was pasted on a harder piece of paper (e.g. 'cartolina' [poster paper]) to ensure its durability for repetitive use.

A lot of the images were decontextualized, for they were not initially meant to be used as instructional 
materials. Such images were removed from their original contexts or media of communication (e.g. magazines and newspapers). Also, a decontextualized image referred to a single entity in the image with no other information available (i.e. linguistic and other visual information) that could help identify the real location of the entity and its purpose, function, or meaning. A lot of the images were procured individually by the teachers, whereas others were submitted by their students as assignments or projects in class. One hundred seventy images were gathered from the Cebuano subject, 209 from Filipino, and 99 from English.

To a large extent, the cultural content of images was linked to their materiality. Colored and printed images may depict the Filipino culture or non-Filipino cultures, or they may show no clear cultural meanings. Printed, yet manually colored images could construct the Filipino culture. Manually drawn and colored images clearly showcased elements of the Butuan culture, if not the Filipino culture.

In Cebuano, there were printed images, for instance, of Coco Martin, a Philippine TV actor who portrayed the local superhero Juan dela Cruz in the Philippine primetime TV Series "Juan dela Cruz." Aside from him, there was an image of Dr. Jose P. Rizal who is one of the Philippine heroes. Likewise, some images of well-known Filipino personalities were used in the Filipino subject. One good example was an image of Kim Chiu who is a popular Filipino actress, host, model, and brand endorser. In English, there were images of 2015 Philippine President Benigno "Noynoy” Aquino III and Manny Pacquiao who is a world renowned boxer.

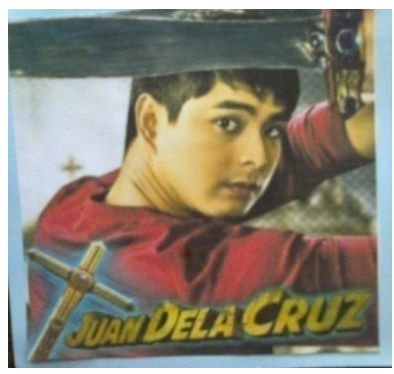

Coco Martin

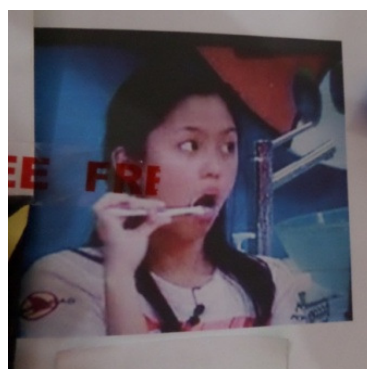

Kim Chiu

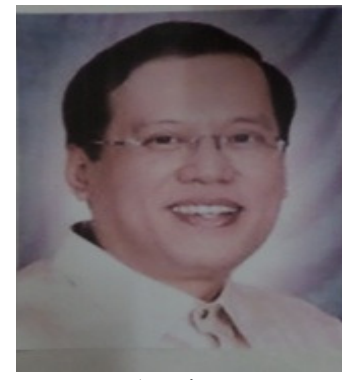

Pres. Aquino III

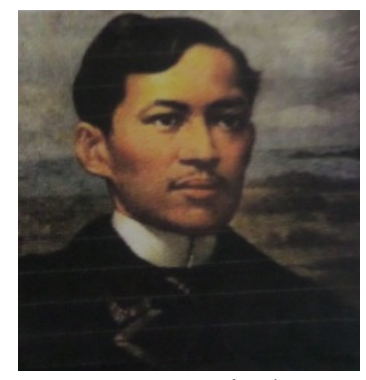

Dr. Jose P. Rizal

Figure 2. Printed images depicting Filipino culture

Other printed and colored images depicted non-Filipino cultures. In Cebuano, there were images of two Chinese-looking students whose school uniforms were typically non-local (i.e. shorts, skirt, and long socks); there were images, too, of a Caucasian fireman, a janitor whose beard and hair were blonde, and a blonde Math teacher. Images of Blair Waldorf, a popular TV actress in the United States, and Justin Bieber, a popular American singer, were used in the Filipino and English subjects, respectively.

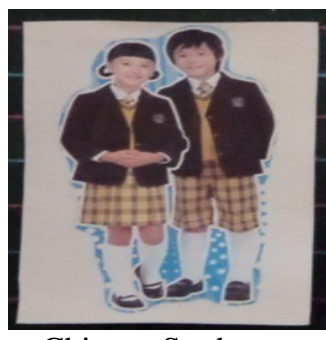

Chinese Students

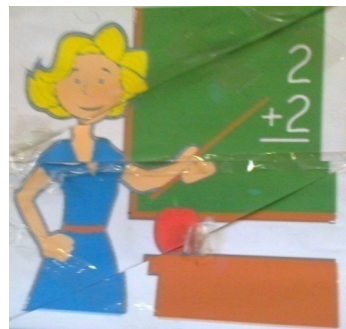

Math Teacher

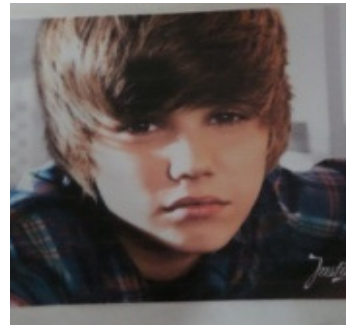

Justin Bieber

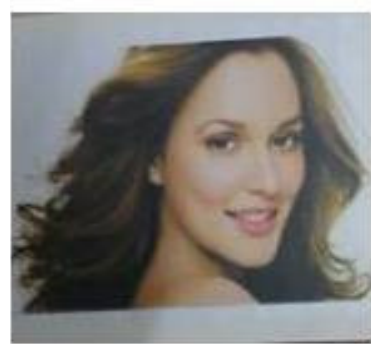

Blair Waldorf

Figure 3. Non-Filipino cultures

Printed yet manually colored images attempted to depict characteristics common to Filipinos. The hair of people or characters in the images was colored either black or brown. 

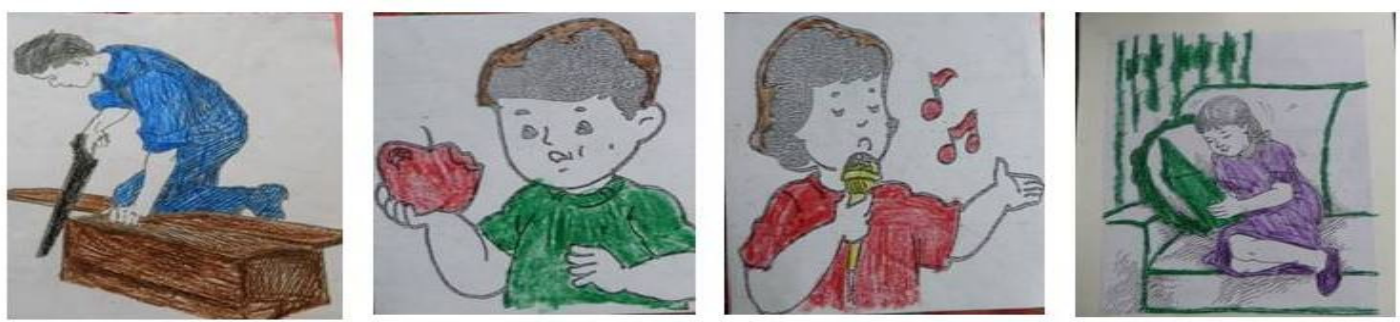

Figure 4. Printed yet manually colored images showing Filipino characteristics

Manually drawn and colored images undoubtedly showcased elements of either the Filipino culture in general or the Butuan culture in particular. In Figure 5, a woman who had black hair was shown doing various activities. Quite interestingly, the woman looked like one of the people seen by the researcher during his stay in Butuan City.

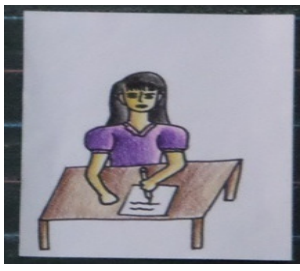

She writes

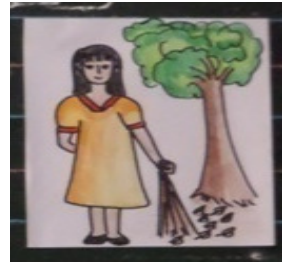

She cleans

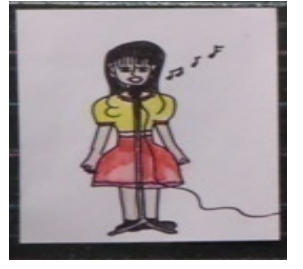

She sings

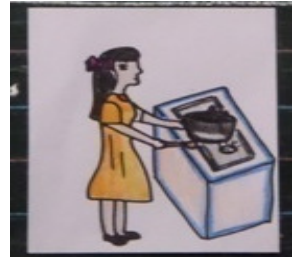

She cooks

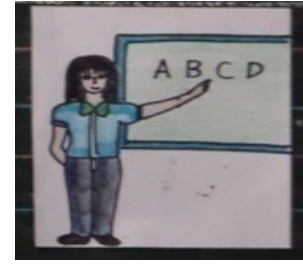

She teaches

Figure 5. A woman who is a member of the Butuan culture

There were images that were devoid of any clear culture, mainly because of their decontextualized nature. Examples of these were images of meat, a dog, and a TV set in Cebuano, of the same dog (reused image) in Filipino, and of an emoticon in English.

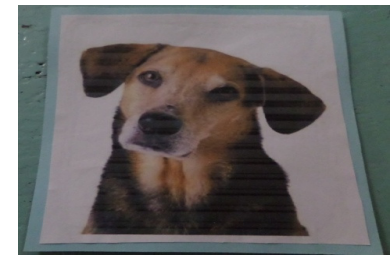

Dog

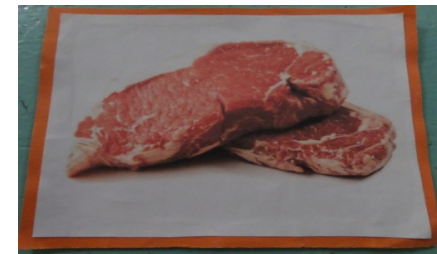

Meat

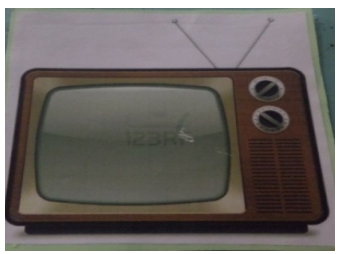

TV Set

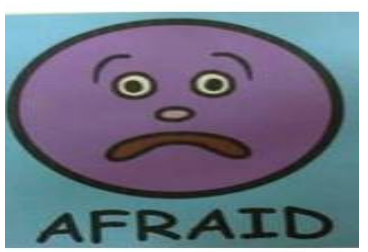

Emoticon

Figure 6. Images with no clear cultural content

\subsection{Cultural discourses in stories and big books}

Stories, in general, could contain all three semiotic modes: linguistic, visual, and materiality. The contents of the stories were very short and simple. After a brief description of the characters, one problem was presented, and after which came the resolution or happy ending. Most of the stories were about people, although there were few stories about personified characters (i.e. animals and food). There were 28 versions of stories or story books in Cebuano, but there were only two short stories in Filipino and three in English. They were called versions of stories because the linguistic content of a story could have different materiality and visual presentation depending on the teachers.

Two patterns existed in the naming of characters in the stories. On the one hand, there were names that sounded distinctly Cebuano and Filipino, and on the other there were "Englishized" names. The names of Ador, Boboy, Estoy, Intoy, Juan, Pedro, Poloy, Lando, Maria, Nilo, and Sisa sound local (i.e. Cebuano and Filipino). Examples of "Englishized" names are Hannah, Jessie, Ted, and Len. Almost all of the main characters were young. 
In general, stories were set in rural areas as evidenced by the abundance of trees, mountains, and grass. The stories revolved around relationships between family members; children's responsibilities at home, in school, and towards themselves; child labor; and Filipinos' smiles and positive attitude in times of adversities. One good example of a distinct Filipino cultural identity was depicted in the stories of Poloy and of Barangay Makugihon [Hardworking Community]. When floods came, Poloy had to climb his way to the roof of his house. He was happy because at least his house was fine and he was safe during and after the flooding. The case of Barangay Makugihon showed a related scenario. Kapitan Morales (Captain Morales) smiled when he delivered the news about the typhoon; people smiled when they procured basic necessities; a teacher smiled when she instructed her students about what to do; and a beaming smile of optimism emanated from the entire community because at least the typhoon had not caused them much damage.

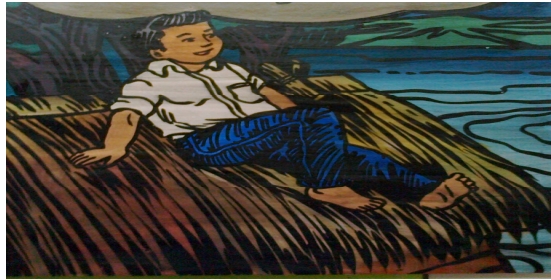

Poloy expresses a sigh of relief.

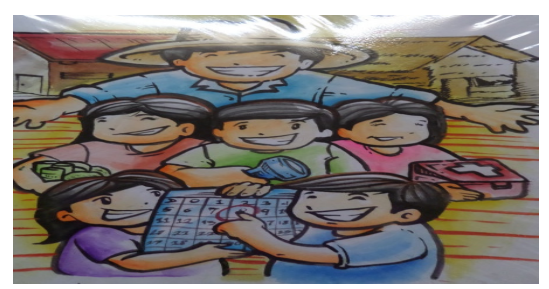

Brgy. Makugihon happily prepares before the coming of typhoon Mendong.

Figure 7. Filipinos' positive attitude in times of adversities

The depth and breadth of cultural information in the stories largely depended on how the materials were produced. Although the teachers used the same linguistic content of stories, their materiality and visual modes differed. For example, a story about a child named Karen who had to sell sampaguita (Arabian jasmine) necklaces to help her family was materially realized differently. Teacher B used a picture she took from the internet, Teacher C drew her own version, and Teacher D acquired her version from one of her students' projects. Because Teacher D's was drawn by a professional artist, hers presented detailed visual information about people besides Karen, houses and other establishments (e.g. stores and church), and activities (e.g. going to church).

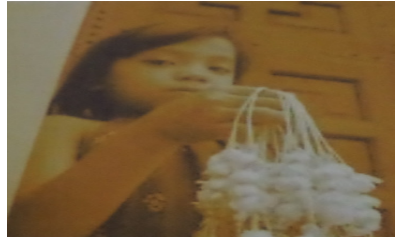

Teacher B's

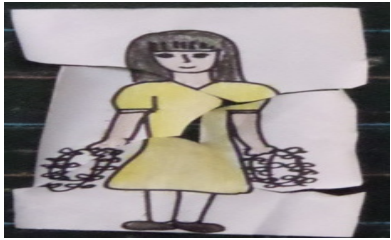

Teacher C's

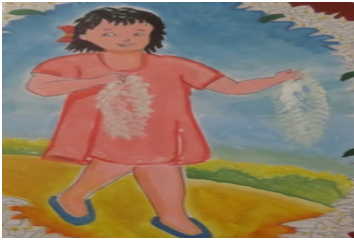

Teacher D's

Figure 8. Different versions of Karen

It was common to all five teachers to have difficulty preparing actual materials for stories. Sometimes, the quality of the material and the clarity of the cultural content were compromised. For instance, Teacher B told her students a story entitled "I Have a Family." The family members were addressed using Filipino terms such as "papa," "mama," and "ate," but all of them possessed characteristics not typical to Filipinos. The children looked different from their parents. Strangely enough, their family picture at the end of the story looked different from their individual images. Apparently, mixed cultural messages were sent to Teacher B's students.

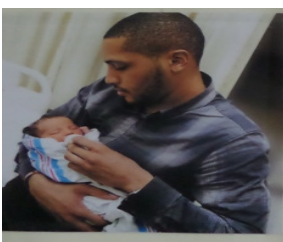

Papa

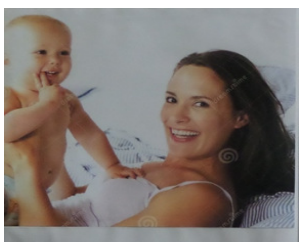

Mama

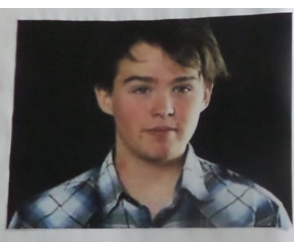

Kuya

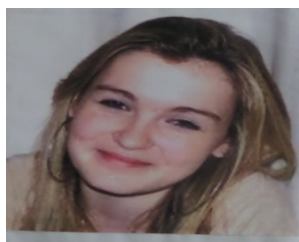

Ate

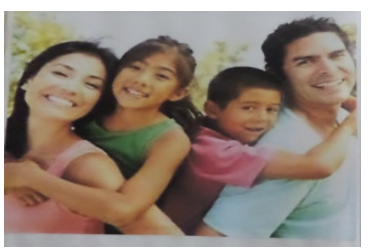

Family Picture

Figure 9. The family members in "I Have a Family" 


\subsection{Cultural discourses in classroom interactions}

In the 163 instances of teacher-student oral interactions in the Cebuano subject, most of the contents or oral modes referred to the Butuan culture (87\%). A few (12\%) constituted the Filipino culture, and the remaining one percent provided a hint of a non-Filipino culture. In the Filipino subject, there were 67 counts of culturally relevant classroom interactions. The Butuan culture took up $76 \%$ of the entire number of instances, the Filipino culture had 14\%, the fused Filipino and Butuan cultures had nine percent, and a non-Filipino culture had only one percent. Despite being the shortest period of classroom observation, the English classes produced 77 interactions with clear cultural contents. Most of the interactions referred to the Butuan culture (90\%), nine percent to the Filipino culture in general, and one percent to non-Filipino cultures.

Generally, the Butuan culture was constructed even if the instructional materials (IMs) were decontextualized and had no clear cultural contents. Furthermore, IMs that presented non-Filipino cultures were used to discuss particular elements of students' source culture. IMs that constructed the Filipino culture were used as a springboard to a more in-depth exploration of either the Filipino culture or the Butuan culture, or both.

In her Filipino class, Teacher A showed her students a decontextualized image of a brain outside a box. As her way of making the image simple and understandable to her students, Teacher A used the image to ask each of her students about his or her brain and where it is found (T=teacher, $\mathrm{S}=$ student, $\mathrm{SS}=$ some students, AS=a lot of students).

Dialogue 1

T: Ito. Ano 'to?

SS: (varied responses)

T: Ito ay isang utak. Ito ay nasa loob ng iyong ulo. Hawakan ang ulo.

AS: (touch their heads)

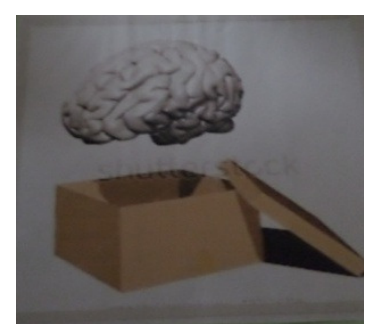

[English translation]

T: This. What is this?

SS: (varied responses)

T: This is a brain. This is inside your head. Touch your head.

AS: (touch their heads)

In her Cebuano class, Teacher B effortlessly used an image of a Western-looking fireman to discuss with her students a real event in Butuan City. Students' answers, which were true to their life experiences, made the interaction culturally meaningful.

Dialogue 2

T: Kinsay nakakita nag tinuod na bombero?

S1: Ako.

S2: Ako, titser, kadtong naay sunog sa Plaza nakakita ko og bombero.

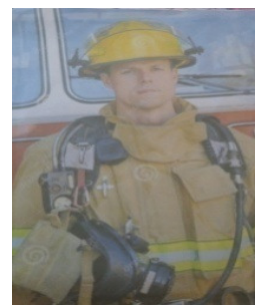


Tagyamon, C., Jr.

[English translation]

$\mathrm{T}$ : Who has seen a real fireman?

S1: Me.

S2: Me, teacher, when there was fire in Plaza (now Guingona Park in Butuan City), I saw a fireman.

After sharing a fictional local story of a boy who had illness, Teacher D recalled one of her students who had a urinary tract infection or UTI. Such a move made the story more relevant to the students.

Dialogue 3

T: Kadto si Noel na naospital, nganong naospital man ka ato, Noel?

S: Kay naghilanat man ko.

T: Nganong naghilanat man ka?

(gap)

T: Ngano man lage? Kinsay nakabalo diri kanang UTI?

SS: Ako (raise their hands).

T: Unsa manang UTI?

SS: (various answers)

T: Okay. Magsige gani ta og kaon og tsitserya og inom og softdrinks, magka-UTI ka. Kanang sakit i?

S: libang.

T: Ha?

S: ihi

T: Sakit i-ihi.

(gap)

T: Mao nang dili gyud ta sigeg kaon og tsitserya, junk foods og inom og softdrinks.

[English translation]

T: When Noel was hospitalized, why were you hospitalized, Noel?

S: Because I had fever.

T: Why did you have fever?

(gap)

T: Why? Who among you know about UTI?

SS: Me (raise their hands).

T: What is UTI? 
A critical analysis of instructional materials and classroom interactions in the mother tongue-based education

SS: (various answers)

T: Okay. If we eat a lot of junk foods and drink soft drinks, you will have UTI. That is when it is painful to?

S: Poo.

T: What?

S: Pee.

T: Painful to pee.

(gap)

T: That is why you should not always eat junk foods and drink soft drinks.

\section{Discussion}

\subsection{No uniform instructional materials}

Despite the efforts of the Department of Education (DepEd) in Butuan City to provide teachers with a curriculum guide, a lesson guide, and learners' materials or work booklets as they are called in this study, not all of them were helpful to the teachers. The work booklets could have been useful resources, but because they were perceived by the teachers as too simple and unchallenging to the students, they decided to use the booklets rarely.

A "do-it-yourself" production of instructional materials (IMs) was commonplace. Although the teachers were provided with soft copies of lesson guides, they were left with the task of producing actual and tangible IMs based on the guides. The lack of already available IMs was something all the five teachers complained about, and the relative freedom to come up with their own IMs posed more problems than opportunities to them. The teachers could not always rely on their salaries to produce their own materials for they had obviously other things to spend for. The teachers' condition led them and their students to more than one possible direction. One was that the teachers produced decontextualized materials which could have adverse effects to the promotion of cultures in class. Also, the teachers transferred to their students some of the responsibility in preparing IMs by requiring them to submit images and create story books. These events led to students' uneven exposure to linguistic and cultural contents. Depending on teachers' and students' resources and capabilities, some materials were rich with linguistic, visual, and cultural information. Some were not.

\subsection{Mixed cultural messages in the IMs}

In the IMs, there was no one-to-one correspondence between a language subject and culture. For example, the cultures constructed in the IMs used in the Cebuano subject were multiple. This condition was not because of the teachers' conscious attempts to challenge the neat one-to-one correspondence. Instead, the multiplicity of cultures was due to the teachers' lack of resources and awareness as to what cultures could be included in each of the language subjects. They were more concerned about presenting images regardless of their quality, size, and content than having no materials to present to students in class. Thus, the teachers' concern was not linguistically and culturally ideological but practical for their everyday survival.

\subsection{Centering the Butuan culture in classroom interactions}

Generally, the Butuan culture was socially constructed through the teachers' questions which were directly addressed to their students and through students' unsolicited comments and relevant responses to teachers' inquiries. For instance, decontextualized IMs and materials presenting non-Filipino cultures were made 
culturally relevant by using them to talk about the knowledge and experiences of the teachers and the students. The interactions proved to be ideological in the sense that three languages can be learned using students' Butuan culture. This finding challenges, first and foremost, the discourse of English cultural imperialism. The native speakers of English are not necessarily considered as the best cultural models of the language.

Much like the case of English, students' learning of another second language-Filipino-will flow naturally and effortlessly when their source or Butuan culture is put at the core of their learning. Thus, the one-to-one correspondence between language subjects and cultures is untenable. People, in general, can possess three or more languages in their linguistic repertoire, but they do not have to give up their cultural or ethnic origins as they attempt to learn languages considered not native to them.

\subsection{Mismatch between goals and actual implementation}

Norman Fairclough's Critical Discourse Analysis moves from microstructures to macrostructural schemes (Fairclough, 1995a, 1995b). In the context of the MTB-MLE in Butuan, the texts (i.e. instructional materials and classroom interactions) did not necessarily reflect the views of institutions that promote multilingualism and multiculturalism in language education. There was a tension between what the documents of the Department of Education (DepEd) say and what the department and the teachers actually do (for more about ethnography in education, see Wolcott, 1987).

The proponents of MTB-MLE claimed that local "experts" should be involved in the production of instructional materials (IMs). The identification and participation of local "experts" were ambiguous. During the focus group discussion (FGD), Teacher A said that she knew that one teacher was assigned to prepare all IMs, particularly in the Cebuano subject. However, this teacher did not even know that it was her responsibility. Even if the teacher knew about her responsibility, she would feel burdened preparing all materials not only for herself but also for her numerous colleagues. The five grade one teachers, then, were left on their own producing their individual IMs. Feeling burdened, they asked assistance from their students in the material preparation and production. Did DepEd refer to students as "experts"? They did not.

\section{Conclusion, Implications, and Recommendations}

\subsection{Conclusion}

"Bemused" would be an understatement to describe the actual condition of the MTB-MLE program. Inconsistencies in cultural discourses exist in the contents within one language subject, among language subjects, and between language subjects and interactions. Word cards in Cebuano, Filipino, and English are not culturally specific. Few word cards, especially the ones about proper nouns, at best provide only names of people, places, things, etc. The cultural practices and perspectives cannot be deduced from such names.

The images in Cebuano, Filipino, and English are similar in some respects. More often than not, printed and colored images are not contextualized; i.e. an entity in an image is shown in plain or no background. Some of the images are locally relevant, while others present non-local cultures. In the case of manually drawn and manually colored images, the characteristics of the people, places, things, etc. are either relevant to the Filipino culture in general or to the Butuan culture in particular. Lacking in all types of images are clear and schematic cultural practices and perspectives due to lack of activity of the people and products depicted in the images and their infrequent occurrence.

In almost all stories, the Filipino culture is prevalent. Filipinos' positive and happy dispositions in life are highlighted through happy endings and smiles of the people amidst difficulties and natural calamities. The materiality, linguistic, and visual modes of the stories affect the manner of presentation and the specificity of cultural information. Due to scarcity of resources, the contents of some stories become confusing; i.e. they are 
A critical analysis of instructional materials and classroom interactions in the mother tongue-based education

local in linguistic content, but they present images belonging to non-Filipino cultures. Unfortunately, the promotion of students' Butuan culture is not emphasized, even in the Cebuano subject. The story books in Cebuano are not necessarily specific to the Butuan culture as there are no names of places and people in Butuan mentioned in the stories.

The construction of culture in the classroom interactions in the Cebuano, Filipino, and English subjects is the most schematic. The classroom interactions challenge the notion of one-to-one correspondence between language subjects and cultures. The one-to-one correspondence looks tidy on the surface. However, it is too simplistic and it does not reflect how languages are used at least in the context of the Philippines. For instance, Cebuano is the language spoken not only by people in Butuan but also by a great many people in the Mindanao and Visayas regions. The use of the English language is not limited to conversations with native speakers of English. Because English is an official language in the Philippines, it can be used as well in business and informal communication among Filipinos across the world and between Filipinos and other non-native speakers of English. The classroom interactions, therefore, suggest that students can remain grounded in their cultural roots or origins as they attempt to learn languages besides their mother tongue.

All the findings show that the actual status and conditions of the implementation of the Mother Tongue-Based Multilingual Education is far from the goals written on paper by the Department of Education and of the United Nations Educational, Scientific and Cultural Organization (UNESCO). The actual materials that are used by the teachers in class reflect not only the lack of funding that the Department of Education provides but also the teachers' lack of sensitivity to the cultural messages that they impart on their students through their instructional materials. Most importantly, it is not clear whether the Butuan culture should be centered in both instructional materials and classroom interactions. All throughout the program, the Butuan culture remains off-centered.

\subsection{Implications and Recommendations}

Although the MTB-MLE program falls short in achieving its goals, there are a lot of insights that can be learned from the program and from the process of acquiring data. The triangulation of classroom observations, Critical Discourses Analysis (CDA), and focus group discussion (FGD) ensures full interpretation of data. In this study, classroom observations are the best, if not the only, means to acquire and make sense of texts (i.e. instructional materials and classroom interactions). Without the classroom observations, this study would not be able to apply Fairclough's CDA and Kress and van Leeuwen's Multimodality mainly because the instructional materials (IMs) generally are not easily accessible, and they only become meaningful once they are used in class.

The texts collected from the classroom observations can be interpreted in many ways; however, using Fairclough's CDA paired with Kress and van Leeuwen's Multimodality, the texts are analyzed systematically, intensively, and extensively. Whereas other studies may only focus on the formal properties of texts, Fairclough's CDA analyzes texts including the institutional and social contexts surrounding the texts. The analysis reveals that the forms of knowledge present in texts are not just products of the semiotic modes but are also resources to critically evaluate the wider contexts in which the texts appear. Though only supplementary to the first two methods, the focus group discussion is nevertheless necessary in probing the researcher's initial judgments about the data. Without it, the interpretation of the data would be less confident and convincing.

This study recommends that future research utilize all three methods. Researchers should not be content with using textbooks which are easily accessible as the only materials to assess language education policies and programs. In addition, they should consider that not all textbooks are used in class and not all classes use textbooks. Therefore, it is necessary that both instructional materials and classroom interactions be analyzed.

To conduct all three methods requires mainly time, resources, and dedication. For future research on the MTB-MLE, this study recommends longer periods of observations, especially for the English subject. English classroom observations can extend to the month of February to acquire more data. Increasing the number of 
teachers to observe may reveal more diversity and nuances in the presentation of the IMs.

Future studies may include other grade levels (e.g. grades two and three) to distinguish the similarities and differences between the IMs and interactions in different grades. Researchers can do comparative analyses not just between grade levels but also between schools. Researchers outside Butuan City can select their own localities and use this present study as their guide. To those studying non-MTB-MLE schools (i.e. private schools), they can analyze textbooks and other instructional materials in class (e.g. videos), and see whether local contents are available in the materials and whether there are discrepancies in the contents of the IMs and the interactions in class. Seeking partnerships with or sponsorships from the Department of Education and other funding institutions can financially aid future researchers.

Language teachers and policy makers all over the world can gain inspiration from the five grade one teachers observed. Although they are constrained by their resources, the five teachers tried their best to make at least the interactions in class meaningful and culturally relevant to their students. Learning Filipino and English, two languages which are not native to Butuanon students, can be possible using students' source culture. Other teachers and students of multilingual education within and outside the Philippines can do the same. They do not have to give up their cultural origins to learn languages not native to them.

Locally, the Department of Education and administrators can use the findings of this study to improve the MTB-MLE program. The "do-it-yourself" production of IMs provides more bane than opportunities to teachers. In the production of IMs, the local "experts" in Butuan City should be tapped. The elementary educators, professors, writers, government officials, non-government organizations, and, of course, the Department of Education in Butuan City should collaborate to come up with stories that depict the real, everyday realities in the city.

The production of actual instructional materials should be done on a large scale so that teachers do not have to spend their time and money to produce their own set of IMs. By producing uniform actual IMs, students are ensured to be exposed at least to similar amount and quality of cultural information that they deserve. The responsibility of producing IMs should not be passed largely to teachers who then pass the work to their students. This passing of burden needs to stop. Work to improve the program needs to continue.

Acknowledgement: I am greatly indebted to my family for without them I will not be where I am now. Also, I would like to thank the Department of Education in Butuan City and the school I observed. Without their approval, I would not have any data to analyze. In interpreting the data, I owe a lot of my skills to my professors at the College of Mass Communication, College of Education, and of course, College of Arts and Letters. To Dr. Aileen O. Salonga (thesis adviser), Dr. Lalaine F. Yanilla Aquino (critic), and Dr. Ma Lorena Santos, Dr. Romylyn Metila, and Dr. Gonzalo Campoamor II (members of the panel), thank you! I truly appreciate your time and expertise.

\section{References}

Ammon, U. (2010). World languages: Trends and futures. In N. Coupland (Ed.), The handbook of language and globalization (pp. 110-122). Oxford, UK: Wiley-Blackwell. http://dx.doi.org/10.1002/9781444324068.ch4

Ball, J. (2010). Enhancing learning of children from diverse language backgrounds: Mother tongue-based bilingual or multilingual education in the early years. Paper commissioned for UNESCO. Retrieved from http://www.basiced.org/wp-content/uploads/Publication_Library/UNESCO-Enhancing_Learning_of_C hildren_from_Diverse_Language_Backgrounds-2010.pdf

Block, D. (2010). Globalization and language teaching. In N. Coupland (Ed.), The handbook of language and globalization (pp. 287-304). Oxford, UK: Wiley-Blackwell.

http://dx.doi.org/10.1002/9781444324068.ch12 
A critical analysis of instructional materials and classroom interactions in the mother tongue-based education

Bloor, M., \& Bloor, T. (2007). The practice of critical discourse analysis: An introduction. Great Britain: Hodder Arnold.

Canagarajah, A.S. (1999). Resisting linguistic imperialism in English teaching. Oxford, UK: Oxford University Press.

Ciprianová , E., \& Vančo, M. (2010). English in the age of globalization: Changing ELT models, restructuring relationships. The Journal of Linguistic and Intercultural Education, 3, 123-136

City Government of Butuan. (2012). About City Government of Butuan. Retrieved March 18, 2015, from http://www.butuan.gov.ph/home/about-butuan/general-info.html

Cortazzi, M., \& Jin, L. (1999). Cultural mirrors: Materials and methods in the EFL classroom. In E. Hinkel (Ed.), Culture in second language teaching and learning (pp.196-219). Cambridge, UK: Cambridge University Press.

Cruz, I. (2010). Mother tongue education. In R. Nolasco, F. Datar, \& A. Azurin (Eds.), Starting where children are: A collection of essays on mother tongue-based multilingual education and language issues in the Philippines (pp. 60-63). Quezon City, Philippines: 170+Talaytayan MLE Inc.

David, M. K., Cavallaro, F., \& Coluzzi, P. (2009). Language policies-impact on language maintenance and teaching: Focus on Malaysia, Singapore, Brunei and the Philippines. In F. Cavallaro, A. Milde, \& P. Sercombe (Eds.), Language, Culture and Identity in Asia. Special Issue of The Linguistics Journal (pp. 155-191). British Virgin Islands: Time Taylor Publications.

Fairclough, N. (1989). Language and power. London, UK: Longman.

Fairclough, N. (1995a). Critical discourse analysis: The critical study of language. London, UK: Longman. Fairclough, N. (1995b). Media discourse. London, UK: Edward Arnold.

Göldner, A. D. (2011). A cultural analysis of first year junior high school EFL textbooks in Japan. Unpublished Thesis, University of Vienna, Vienna, Austria.

Jahan, A. (2012). Residual cultural imperialism in primary textbooks in Bangladesh: A critique of the English for Today textbooks. East West Journal of Humanities, 3, 73-94.

Jambor, P. (2007). English language imperialism - points of view. The Journal of English as an International Language, 1, 103-123.

Kress, G., \& van Leeuwen, T. (2006). Reading images: The grammar of visual design (2nd ed.). London, UK: Routledge.

Mahmood, M. A., Asghar, Z. M., \& Hussain, Z. (2012). Cultural representation in ESL textbooks in Pakistan: A case study of Step Ahead 1. Journal of Education and Practice, 3(9), 35-42.

Malone, S. (2007). Mother tongue-based multilingual education: Implications for education policy. Paper presented at the Education policy and the right to education: Towards more equitable outcomes for South Asia's children seminar, Kathmandu, Nepal. Retrieved from http://resources.wycliffe.net/pdf/MT-Based\%20MLE\%20programs.pdf

Moran, P. (2001). Teaching culture: Perspectives in practice. Australia: Heinle \& Heinle.

Nolasco, R. M. (2008). The prospects of multilingual educational and literacy in the Philippines. In A. B.

Bernardo (Ed.), The paradox of Philippine education and education reform: Social science perspectives (pp. 133-145). Quezon City, Philippines: Philippine Social Science Council.

Nolasco, R. (2009). 21 reasons why Filipino children learn better while using their Mother Tongue. Philippines: Guro Formation Forum, University of the Philippines.

Nolasco, R. (2010). Fixing education through language. In R. Nolasco, F. Datar, \& A. Azurin (Eds.), Starting where children are: A collection of essays on mother tongue-based multilingual education and language issues in the Philippines (pp. 106-108). Quezon City, Philippines: 170+Talaytayan MLE Inc.

Nolasco, R., Datar, F., \& Azurin, A. (Eds.). (2010). Starting where children are: A collection of essays on mother tongue-based multilingual education and language issues in the Philippines. Quezon City, Philippines: 170+Talaytayan MLE Inc.

Official Gazette. (2015). The 1987 constitution of the republic of the Philippines-Article XIV. Retrieved from http://www.gov.ph/the-philippine-constitutions/the-1987-constitution-of-the-republic-of-the-philippines /the-1987-constitution-of-the-republic-of-the-philippines-article-xiv/ 
Tagyamon, C., Jr.

Phillipson, R. (1992). Linguistic imperialism. Oxford, UK: Oxford University Press.

Shah, S. K., Afsar, A., Fazal e Haq, H. M., \& Khan, Z. A. (2012). Course contents of English language textbooks and their relevance to learners' culture in an Islamic context. Journal of Education and Practice, 3(12), $165-180$.

Sy-Kho, R. (2012, June 12). K to12: Lessons to be taught in mother tongue to help students learn better and stay in school. GMA News Online. Retrieved from http://www.gmanetwork.com/news/story/260658/news/specialreports/k-to12lessons-to-be-taught-in-mo ther-tongue-to-help-students-learn-better-and-stay-in-school

Tajima, M. (2008). A critical analysis of an approved English textbook for lower secondary school students in Japan: Embedded cultural values and ideologies. Seijo English Monographs, 40, 195-239.

Titscher, S., Meyer, M., Wodak, R., \& Vetter, E. (2000). Methods of text and discourse analysis [In German]. London, UK: Sage.

Tupas, R. (2002). Second language teaching. Quezon City, Philippines: University of the Philippines Open University.

United Nations Educational, Scientific and Cultural Organization. (2003). Education in a multilingual world. Paris, France: UNESCO.

van Leeuwen, T. (2005). Introducing social semiotics. London, UK: Routledge.

Wolcott, H. (1987). On ethnographic intent. In G. Spindler \& L. Spindler (Eds.), Interpretive ethnography of education: At home and abroad (pp. 37-58). Hillsdale, NJ: Erlbaum. 